\title{
Contents
}

\section{Volume 63 (2009)}

Editorial

\section{Original Papers}

Almeida, G., J.O. Brito and P. Perre:

Changes in wood-water relationship due to heat treatment assessed on micro-samples

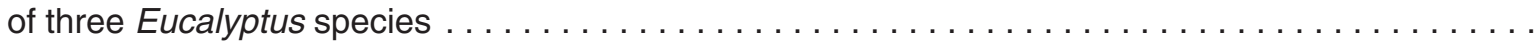

Ban, W., Q. Liu, J. Guo, H. Mao and L.A. Lucia:

A study of anthraquinone-fortified green liquor pretreatment of loblolly pine chips

Berg, J.-E., M.E. Gulliksson and P.A. Gradin:

On the energy consumption for crack development in fibre wall in disc refining -

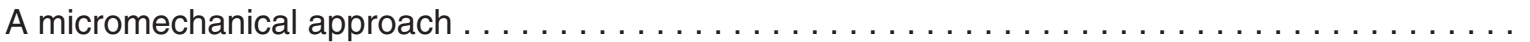

Bogren, J., H. Brelid, M. Bialik and H. Theliander:

Impact of dissolved sodium salts on kraft cooking reactions $\ldots \ldots \ldots \ldots \ldots$

Brodin, I., E. Sjöholm and G. Gellerstedt:

Kraft lignin as feedstock for chemical products: The effects of membrane filtration . . . . . . . . . .

Carneiro, J.S., L. Emmert, J.C. Mendes, G.H. Sternatdt and G. Almeida:

Decay susceptibility of used or lesser-used Amazon wood species from Brazil against

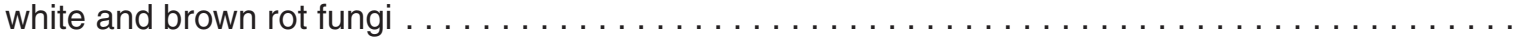

Chirkova, J., I. Irbe, I. Andersone and B. Andersons:

Study of the sorption-desorption properties of pine wood at the initial stage of decay

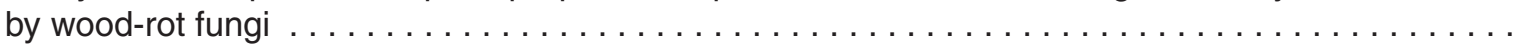

Chu, F.-H., P.-M. Kuo, Y.-R. Chen and S.-Y. Wang:

Cloning and characterization of $\alpha$-pinene synthase from Chamaecyparis formosensis Matsum . . . . .

de Moura, M.F.S.F., M.A.L. Silva, J.J.L. Morais, A.B. de Morais and J.J.L. Lousada:

Data reduction scheme for measuring $G_{\text {IIc }}$ of wood in end-notched flexure (ENF) tests. . . . . . . .

Delmas, D., D. Lachenal, G. Mortha, N. Marlin and C. Calais:

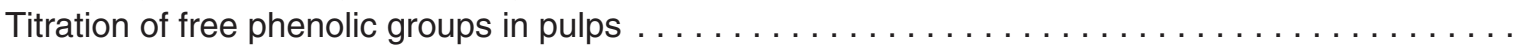

Dieste, A., A. Krause, C. Mai, G. Sèbe, S. Grelier and H. Militz:

Modification of Fagus sylvatica L. with 1,3-dimethylol-4,5-dihydroxy ethylene urea (DMDHEU).

Part 2: Pore size distribution determined by differential scanning calorimetry $\ldots \ldots \ldots \ldots \ldots$

Dlouhá, J., B. Clair, O. Arnould, P. Horáček and J. Gril:

On the time-temperature equivalency in green wood: Characterisation of viscoelastic

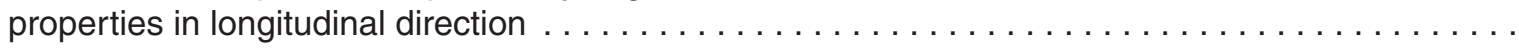

Donoso-Fierro, C., J. Becerra, E. Bustos-Concha and M. Silva:

Chelating and antioxidant activity of lignans from Chilean woods (Cupressaceae) . . . . . . . . .

Eberhardt, T.L., C.-L. So, A. Protti and P.-W. So:

Gadolinium chloride as a contrast agent for imaging wood composite components by magnetic

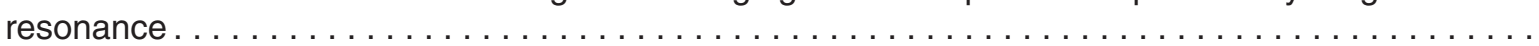

Elustondo, D.M., L. Oliveira and P. Lister:

Temperature drop sensor for monitoring kiln drying of lumber $\ldots \ldots \ldots \ldots \ldots \ldots \ldots$

Evtuguin, D.V., G. Rocha and B.J. Goodfellow:

Detection of muconic acid type structures in oxidized lignins using 2D NMR spectroscopy. . . . . .

Feng, X., D. Zhang and R. Pelton:

Adhesion to wet cellulose - Comparing adhesive layer-by-layer assembly to coating polyelectrolyte

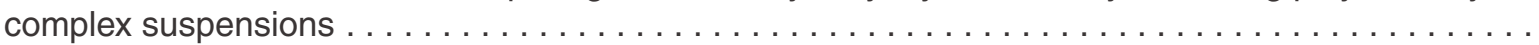

Gentz, M.C., J.K. Grace and M.E. Mankowski:

Horizontal transfer of boron by the Formosan subterranean termite (Coptotermes formosanus

Shiraki) after feeding on treated wood $\ldots \ldots \ldots \ldots \ldots \ldots \ldots \ldots \ldots \ldots \ldots \ldots \ldots \ldots$

Gereke, T., P.J. Gustafsson, K. Persson and P. Niemz:

Experimental and numerical determination of the hygroscopic warping of cross-laminated solid wood panels 
Goetz, L.A., J.P. Sladky and A.J. Ragauskas:

Analysis of microwave vs. thermally assisted grafting of poly(methyl-vinyl ether co-maleic

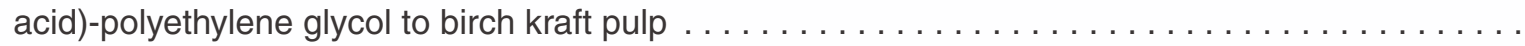

González-Peña, M.M. and M.D.C. Hale:

Colour in thermally modified wood of beech, Norway spruce and Scots pine. Part 1:

Colour evolution and colour changes . . . . . . . . . . . . . . . . . . . . . . . . .

González-Peña, M.M. and M.D.C. Hale:

Colour in thermally modified wood of beech, Norway spruce and Scots pine. Part 2:

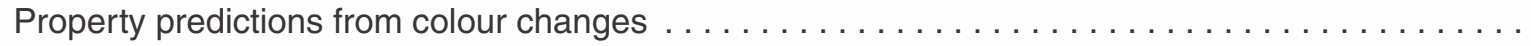

Gradinger, C., T. Boisselet, D. Stratev, T. Ters, K. Messner and K. Fackler:

Biological control of sapstain fungi: From laboratory experiments to field trials $\ldots \ldots \ldots \ldots \ldots \ldots$

Granholm, K., P. Su, L. Harju and A. Ivaska:

Study on desorption of $\mathrm{Mn}, \mathrm{Fe}$, and Mg from TMP and evaluation of the complexing

strength of different chelating agents using side reaction coefficients $\ldots \ldots \ldots \ldots \ldots \ldots \ldots \ldots$

Gregorova, A., R. Wimmer, M. Hrabalova, M. Koller, T. Ters and N. Mundigler:

Effect of surface modification of beech wood flour on mechanical and thermal properties of

poly (3-hydroxybutyrate)/wood flour composites. . . . . . . . . . . . . . . . . . . . .

Hart, P.W., D.M. Waite, L. Thibault, J. Tomashek, M.-E. Rousseau, C. Hill and M.J. Sabourin:

Selective enzyme impregnation of chips to reduce specific refining energy in alkaline peroxide

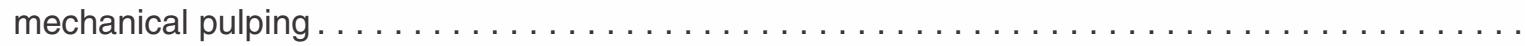

Hashida, K., R. Makino and S. Ohara:

Amination of pyrogallol nucleus of condensed tannins and related polyphenols by ammonia

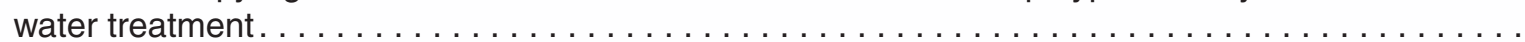

Hedjazi, S., O. Kordsachia, R. Patt and A. Kreipl:

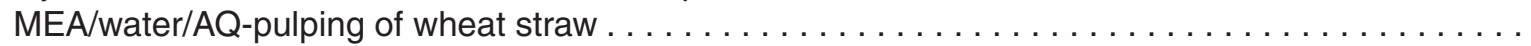

Herritsch, A. and J.J. Nijdam:

An improved drying model for highly-impermeable hardwoods . .

Hill, C.A.S., S.F. Curling, J.H. Kwon and V. Marty:

Decay resistance of acetylated and hexanoylated hardwood and softwood species exposed to

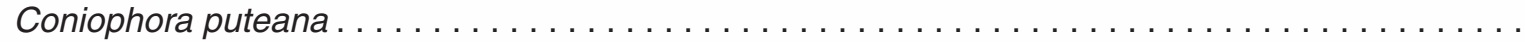

Hislop, G., A.D. Hellicar, L. Li, K. Greene, C. Lewis and R. Meder:

Microwave radar for detection of resin defects in Pinus elliottii Engelm var elliottii. . . . . . . . . .

lakovlev, M., T. Pääkkönen and A. van Heiningen:

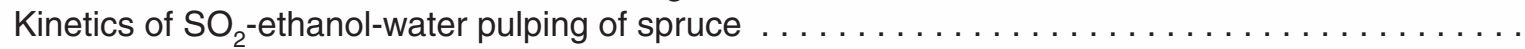

Ibarra, D., V. Köpcke and M. Ek:

Exploring enzymatic treatments for the production of dissolving grade pulp from

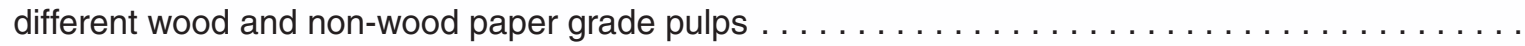

Jääskeläinen, A.-S., K. Toikka, A. Lähdetie, T. Liitiä and T. Vuorinen:

Reactions of aromatic structures in brightness reversion of fully-bleached eucalyptus kraft pulps . .

Ji, Y., E. Vanska and A. van Heiningen:

New kinetics and mechanisms of oxygen delignification observed in a continuous

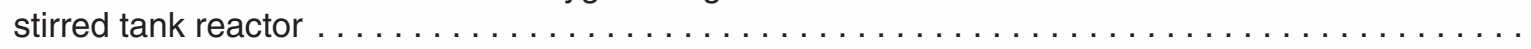

Kim, G.-H., Y.W. Lim, Y.-S. Choi, M.-J. Kim and J.-J. Kim:

Primary and secondary decay fungi on exposed pine tree logs in the forest . . . . . . . . . . .

Kim, J.-K. and Y.-S. Bae:

Grandidentatin isomer from bark of suwon poplar (Populus alba L.xPopulus glandulosa Uyeki). ...

Konishi, F., T. Yokoyama and Y. Matsumoto:

Investigation of hydrogen abstraction from methyl glucoside by active oxygen species under

oxygen delignification conditions. Part 1: Study on the anomeric position . . . . . . . . . . . .

Krainz, K., A. Potthast, U. Suess, T. Dietz, N. Nimmerfroh and T. Rosenau:

Effects of selected key chromophores on cellulose integrity upon bleaching . . . . . . . . . . . .

Lähdetie, A., T. Liitiä, T. Tamminen, J. Pere and A.-S. Jääskeläinen:

Activation of thermomechanical pulp by laccases as studied by UV-Vis, UV resonance Raman

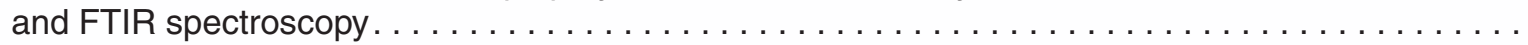

Laka, M. and S. Chernyavskaya:

Effect of salts on the formation and properties of microcrystalline cellulose and chitosan gels .....

571

Lapierre, L., J. Bouchard and R. Berry:

The relationship found between fibre length and viscosity of three different

commercial kraft pulps 
Lee, S.-H., S. Wang, T. Endo and N.-H. Kim:

Visualization of interfacial zones in lyocell fiber-reinforced polypropylene composite by

AFM contrast imaging based on phase and thermal conductivity measurements $\ldots \ldots \ldots \ldots \ldots$

Li, P., C. Dai and S. Wang:

A simulation of void variation in wood-strand composites during consolidation . . . . . . . . . .

Liebner, F., E. Haimer, A. Potthast, D. Loidl, S. Tschegg, M.-A. Neouze, M. Wendland and T. Rosenau:

Cellulosic aerogels as ultra-lightweight materials. Part 2: Synthesis and properties $\ldots \ldots \ldots \ldots \ldots$

Mannes, D., L. Josic, E. Lehmann and P. Niemz:

Neutron attenuation coefficients for non-invasive quantification of wood properties $\ldots \ldots \ldots \ldots$.

Mannes, D., W. Sonderegger, S. Hering, E. Lehmann and P. Niemz:

Non-destructive determination and quantification of diffusion processes in

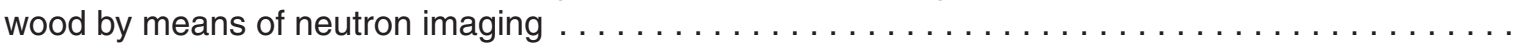

Mansfield, S.D., R. Parish, C.M. Di Lucca, J. Goudie, K.-Y. Kang and P. Ott:

Revisiting the transition between juvenile and mature wood: a comparison of fibre length,

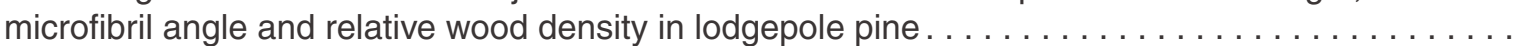

Masarin, F., P.C. Pavan, M.P. Vicentim, P.B. Souza-Cruz, C. Loguercio-Leite and A. Ferraz:

Laboratory and mill scale evaluation of biopulping of Eucalyptus grandis Hill ex Maiden with

Phanerochaete chrysosporium RP-78 under non-aseptic conditions. . . . . . . . . . . . .

Megiatto Jr., J.D., E. Cazeils, S. Grelier, C. Gardrat, F. Ham-Pichavant and A. Castellan:

Synthesis of a lignin polymer model consisting of only phenolic $\beta-O-4$ linkages and

testing its reactivity under alkaline conditions. . . . . . . . . . . . . . . . . . . . . . . . . .

Mendes, C.V.T., C.M.S.G. Baptista, J.M.S. Rocha and M.G.V.S. Carvalho:

Prehydrolysis of Eucalyptus globulus Labill. hemicelluloses prior to pulping and

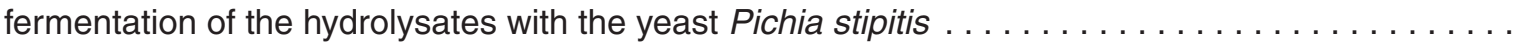

Merela, M., P. Oven, I. Serša and U. Mikac:

A single point NMR method for an instantaneous determination of the moisture

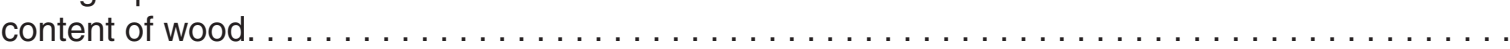

Mittal, A., S.G. Chatterjee, G.M. Scott and T.E. Amidon:

Modeling xylan solubilization during autohydrolysis of sugar maple wood meal:

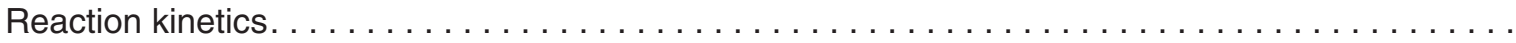

Moutinho, I.M.T., A.M. Kleen, M.M.L. Figueiredo and P.J.T. Ferreira:

Effect of surface sizing on the surface chemistry of paper containing eucalyptus pulp $\ldots \ldots \ldots \ldots$

Nagy, M., K. David, G.J.P. Britovsek and A.J. Ragauskas:

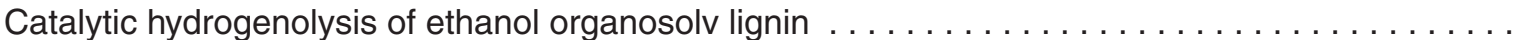

Namyslo, J.C. and D.E. Kaufmann:

Chemical improvement of surfaces. Part 1: Novel functional modification of wood with

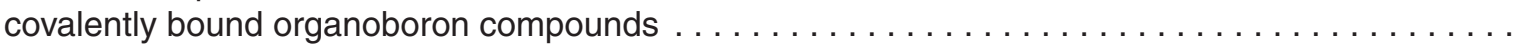

Nanayakkara, B., M. Manley-Harris, I.D. Suckling and L.A. Donaldson:

Quantitative chemical indicators to assess the gradation of compression wood $\ldots \ldots \ldots \ldots \ldots$

Nishimura, T. and M. Ishihara:

Action of fungal $\beta$-glucosidase on the mono- $O$-methylated $p$-nitrophenyl $\beta$-D-glucopyranoside . ....

Normakhamatov, N.S., A.S. Turaev and N.D. Burkhanova:

Cellulose supramolecular structure changes during chemical activation and sulfation

Nousiainen, P., P. Maijala, A. Hatakka, A.T. Martínez and J. Sipilä:

Syringyl-type simple plant phenolics as mediating oxidants in laccase catalyzed degradation of lignocellulosic materials: Model compound studies $\ldots \ldots \ldots \ldots \ldots \ldots \ldots \ldots \ldots \ldots \ldots \ldots \ldots$

Okita, Y., T. Saito and A. Isogai:

TEMPO-mediated oxidation of softwood thermomechanical pulp

Oliveira, J.M.Q., M.F.S.F. de Moura and J.J.L. Morais:

Application of the end loaded split and single-leg bending tests to the mixed-mode fracture

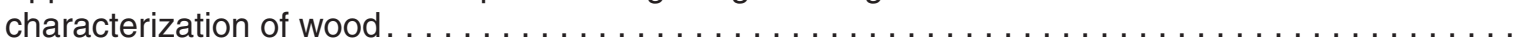

Patel, I., R. Ludwig, K. Mueangtoom, D. Haltrich, T. Rosenau and A. Potthast:

Comparing soluble Trametes pubescens laccase and cross-linked enzyme crystals (CLECs) for enzymatic modification of cellulose.

Pfriem, A., M. Zauer and A. Wagenführ:

Alteration of the pore structure of spruce (Picea abies (L.) Karst.) and maple

(Acer pseudoplatanus $\mathrm{L}$.) due to thermal treatment as determined by helium pycnometry

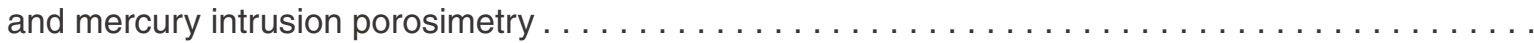


Potthast, A., S. Schiehser, T. Rosenau and M. Kostic:

Oxidative modifications of cellulose in the periodate system - Reduction and beta-elimination

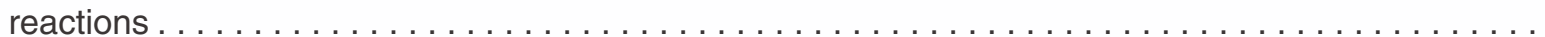

Prislan, P., G. Koch, K. Čufar, J. Gričar and U. Schmitt:

Topochemical investigations of cell walls in developing xylem of beech (Fagus sylvatica L.). . . . .

Rencoret, J., G. Marques, A. Gutiérrez, L. Nieto, J.I. Santos, J. Jiménez-Barbero,

Á.T. Martínez and J.C. del Río:

HSQC-NMR analysis of lignin in woody (Eucalyptus globulus and Picea abies) and

non-woody (Agave sisalana) ball-milled plant materials at the gel state.

Robinson, S.C., D.L. Richter and P.E. Laks:

Effects of substrate on laboratory spalting of sugar maple.

Saarinen, T., A. Suurnäkki, M. Österberg and J. Laine:

Modification of lignin with laccases for the adsorption of anionic ferulic acid studied by

quartz cristall microbalance with dissipation and AFM . . . . . . . . . . . . . . . . . . .

Schimleck, L.R., C. Espey, C.R. Mora, R. Evans, A. Taylor and G. Muniz:

Characterization of the wood quality of pernambuco (Caesalpinia echinata Lam) by measurements of density, extractives content, microfibril angle, stiffness, color, and

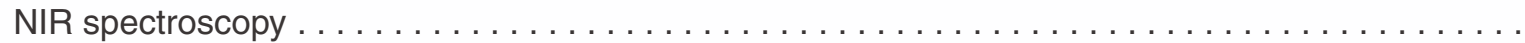

Schubert, S., D. Gsell, J. Dual, M. Motavalli and P. Niemz:

Acoustic wood tomography on trees and the challenge of wood heterogeneity . . . . . . . . .

Shulga, G., V. Shakels, O. Aniskevicha, J. Zakharova and S. Skudra:

Interfacial properties of polyelectrolyte complexes incorporating kraft lignin $\ldots \ldots \ldots \ldots \ldots$

Skyba, O., P. Niemz and F.W.M.R. Schwarze:

Resistance of thermo-hygro-mechanically (THM) densified wood to degradation by

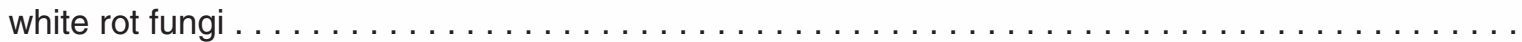

Speranza, M., A. Gutiérrez, J.C. del Río, L. Bettucci, Á.T. Martínez and M.J. Martínez:

Sterols and lignin in Eucalyptus globulus Labill. wood: Spatial distribution and fungal

removal as revealed by microscopy and chemical analyses. . . . . . . . . . . . . . . . . . . .

Stanzl-Tschegg, S., W. Beikircher and D. Loidl:

Comparison of mechanical properties of thermally modified wood at growth ring and

cell wall level by means of instrumented indentation tests

482

Stevanic, J.S. and L. Salmén:

Orientation of the wood polymers in the cell wall of spruce wood fibres.

Strey, G., J. Wesley-Smith and F. Wolfaardt:

The influence of mannanase and endoglucanase treatment on the fibre stability of spruce CTMP.....

Suchy, M., T. Hakala, H. Kangas, E. Kontturi, T. Tammelin, T. Pursula and T. Vuorinen:

Effects of commercial cellobiohydrolase treatment on fiber strength and morphology of

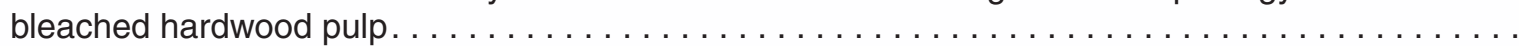

Sugimoto, T., K. Magara, S. Hosoya, S. Oosawa, T. Shimoda and K. Nishibori:

Ozone pretreatment of lignocellulosic materials for ethanol production:

Improvement of enzymatic susceptibility of softwood $\ldots \ldots \ldots \ldots \ldots \ldots \ldots \ldots \ldots \ldots \ldots$

Tarmian, A. and P. Perré:

Air permeability in longitudinal and radial directions of compression wood of Picea abies L.

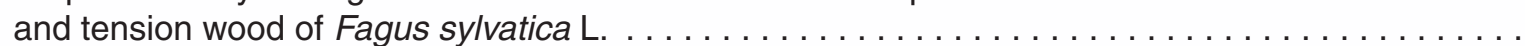

Terashima, N., T. Akiyama, S. Ralph, D. Evtuguin, C.P. Neto, J. Parkås, M. Paulsson,

U. Westermark and J. Ralph:

2D-NMR (HSQC) difference spectra between specifically ${ }^{13} \mathrm{C}$-enriched and unenriched

protolignin of Ginkgo biloba obtained in the solution state of whole cell wall material . . . . . . . . .

Tot, I., Y. Müller, C. Werner, T. Rosenau and A. Potthast:

A novel, mild and selective methylation of carboxyl groups in cellulosic pulps . . . . . . . . . . .

Verma, P., U. Junga, H. Militz and C. Mai:

Protection mechanisms of DMDHEU treated wood against white and brown rot fungi $\ldots \ldots \ldots \ldots$

Vicentim, M.P., R. de Almeida Faria and A. Ferraz:

High-yield kraft pulping of Eucalyptus grandis Hill ex Maiden biotreated by Ceriporiopsis

subvermispora under two different culture conditions. . . . . . . . . . . . . . . . . . . . .

Walther, T. and $\mathrm{H}$. Thoemen:

Synchrotron X-ray microtomography and 3D image analysis of medium density

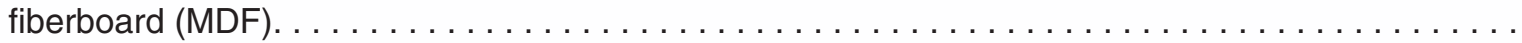


Warsta, E., T. Vuorinen and M. Pitkänen:

Addition of bisulphite to lignin $\alpha$-carbonyl groups: A study on model compounds and

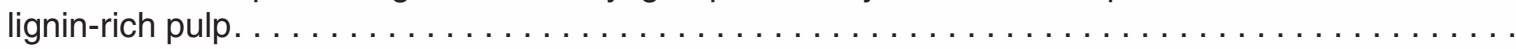

Watanabe, T., H. Kawamoto and S. Saka:

Radical chain reactions in pyrolytic cleavage of the ether linkages of lignin model

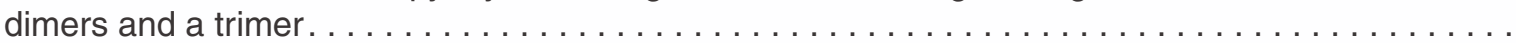

Wei, M., G. Yang, Y. Tian, H. Shao and X. Hu:

Formation of the crystal structure of Lyocell fiber during drying.

Westman, E.-H., M. Ek and L. Wågberg:

Antimicrobial activity of polyelectrolyte multilayer-treated cellulose films $\ldots \ldots \ldots \ldots \ldots \ldots \ldots$.

Widsten, P., A. Hummer, C. Heathcote and A. Kandelbauer:

A preliminary study of green production of fibreboard bonded with tannin and laccase

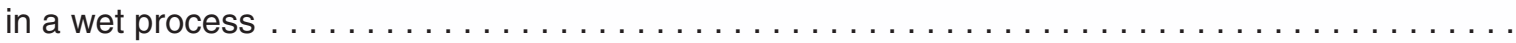

Wie, Q., S.Y. Zhang, Y.H. Chui and B. Leblon:

Reconstruction of 3D images of internal log characteristics by means of successive

2D log computed tomography images . . . . . . . . . . . . . . . . . . . . . . . . .

Willför, S., M. Ali, M. Karonen, M. Reunanen, M. Arfan and R. Harlamow:

Extractives in bark of different conifer species growing in Pakistan . . . . . . . . . . . . . .

Windeisen, E., H. Bächle, B. Zimmer and G. Wegener:

Relations between chemical changes and mechanical properties of thermally treated wood ......

Xavier, J.M.C., M. Oliveira, J. Morais and T. Pinto:

Measurement of the shear properties of clear wood by the Arcan test. . . . . . . . . . . . . .

Xu, C., A. Pranovich, J. Hemming, B. Holmbom, S. Albrecht, H.A. Schols, S. Willför:

Hydrolytic stability of water-soluble spruce $O$-acetyl galactoglucomannans. . . . . . . . . . .

Yang, G., Y. Zhang, H. Shao and X. Hu:

A comparative study of bamboo Lyocell fiber and other regenerated cellulose fibers

Yoshihara, $\mathrm{H}$.:

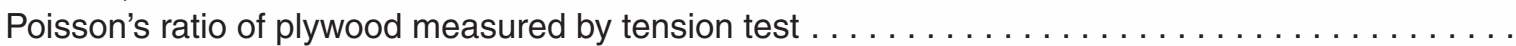

Yoshihara, $\mathrm{H}$.:

Shear properties of wood measured by the asymmetric four-point bending test of

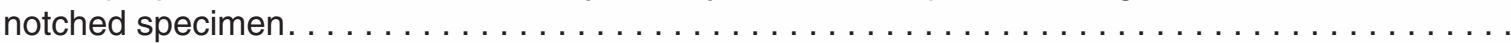

Zhou, C., G.D. Smith and C. Dai:

Characterizing hydro-thermal compression behaviour of aspen wood strands $\ldots \ldots \ldots \ldots \ldots$

Zollfrank, C. and J. Fromm:

Ultrastructural development of the softwood cell wall during pyrolysis $\ldots \ldots \ldots \ldots \ldots \ldots \ldots$

\section{Review articles}

Hofstetter, K. and E.K. Gamstedt:

Hierarchical modelling of microstructural effects on mechanical properties of wood. A review .....

Landis, E.N. and P. Navi:

Modeling crack propagation in wood and wood composites. A review . . . . . . . . . . . . .

Marchal, R., F. Mothe, L.-E. Denaud, B. Thibaut and L. Bleron:

Cutting forces in wood machining - Basics and applications in industrial processes. A review .....

Navi, P. and S. Stanzl-Tschegg:

Micromechanics of creep and relaxation of wood. A review . . . . . . . . . . . . . . . . . . .

Orlowski, K.A. and B. Palubicki:

Recent progress in research on the cutting processes of wood. A review $\ldots \ldots \ldots \ldots \ldots \ldots \ldots$

Salmén, L. and I. Burgert:

Cell wall features with regard to mechanical performance. A review $\ldots \ldots \ldots \ldots \ldots \ldots \ldots$

Sinn, G., J. Sandak and T. Ramananantoandro:

Properties of wood surfaces - characterisation and measurement. A review. . . . . . . . . .

Stanzl-Tschegg, S.E. and P. Navi:

Fracture behaviour of wood and its composites. A Review. .

Wyeth, D.J., G. Goli and A.G. Atkins:

Fracture toughness, chip types and the mechanics of cutting wood. A review .

\section{Short Notes}

Barnes, H.M., G.B. Lindsey and J.M. Hill:

Effect of copper xyligen treatment on bending properties of wood. 
Östlund, A. and M. Nydén:

Determination of self-diffusion coefficient and hydrodynamic radius of xylan by

NMR diffusometry (NMRd)

Penneru, A.P., D. Bhattacharyya and K. Jayaraman:

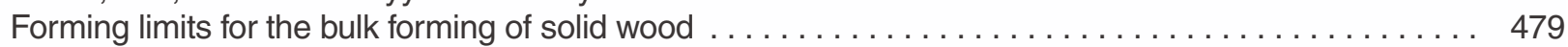

Si, C.-L., L. Wu, Z.-Y. Zhu, J.-K. Kim, D.-J. Kwon and Y.-S. Bae:

Apigenin derivatives from Paulownia tomentosa Steud. var. tomentosa stem barks

Personalia 